\title{
PENGEMBANGAN MEDIA PEMBELAJARAN IPS BERBASIS VIDEO ANIMASI PADA TEMA INDAHNYA KERAGAMAN DI NEGERIKU
}

\author{
Audita Alfianti, M. Taufik, Zerri Rahman Hakim \\ Universitas Sultan Ageng Tirtayasa \\ auditaalfianti4@gmail.com, taufikmalalak@gmail.com, zerrirahmanhakim@gmail.com
}

\begin{abstract}
Abstrak
Penelitian ini bertujuan untuk mengetahui kelayakan dan respon siswa terhadap media pembelajaran IPS berbasis video animasi. Penelitian ini dilakukan di SDN Panancangan 2 dengan subjek penelitian di kelas IV dengan 20 orang siswa pada uji coba terbatas. Metode penelitian yang digunakan adalah metode penelitian dan pengembangan yang telah dikembangkan oleh Sugiyono yang terdiri dari 6 tahapan yaitu analisis masalah, pengumpulan data, desain produk, validasi desain, revisi desain, uji coba produk. Video animasi di validasi oleh para ahli yaitu ahli materi, ahli media, dan ahli bahasa, selanjutnya dilakukan uji coba produk kepada siswa. Hasil uji validasi para ahli sebesar 79,9\% dengan kriteria layak. Hasil uji coba produk sebesar 86,2\% dengan kriteria sangat baik. Berdasarkan hasil penelitian dapat disimpulkan bahwa media video animasi layak untuk digunakan dalam pembelajaran IPS pada tema indahnya keragaman di negeriku.
\end{abstract}

Kata kunci : media pembelajaran, IPS, video animasi.

\begin{abstract}
This study aims to determine the feasibility and response of students to media learning based on animated video animation. This research was conducted at SDN Panancangan 2 with research subjects in class IV with 20 students on a limited trial. The research method used is a research and development method that has been developed by Sugiyono consisting of 6 stages namely problem analysis, data collection, product design, design validation, design revision, product trials. Animated videos are validated by experts namely material experts, media experts, and linguists, then the product is tested on students. The validation test results of experts amounted to $79.9 \%$ with reasonable criteria. Product trial results of $86.2 \%$ with very good criteria. Based on the results of the study it can be concluded that the video animation media is appropriate to be used in social studies learning on the beautiful theme of diversity in my country.
\end{abstract}

Keywords :learning media, social sciences, animated video.

\section{PENDAHULUAN}

Pendidikan sebagai penggerak perubahan individu, dengan adanya pendidikan seseorang dapat memperoleh ilmu pengetahuan. Pendidikan merupakan faktor utama dalam membentuk karakter bangsa, pendidikan menurut UU No. 20 tahun 2003 yaitu usaha sadar dan terencana untuk mewujudkan suasana belajar dan proses pembelajaran agar peserta didik secara aktif mengembangkan potensi dirinya untuk memiliki kekuatan spiritual keagamaan, pengendalian diri, kepribadian, kecerdasan, akhlak mulia, serta keterampilan yang diperlukan dirinya, masyarakat, bangsa dan Negara. Pendidikan direncanakan secara sistematis, oleh sebab itu kurikulum sangat penting bagi pendidikan siswa.

Kurikulum merupakan program pendidikan yang disediakan oleh lembaga pendidikan, berdasarkan program tersebut siswa melakukan berbagai kegiatan belajar. 
Kurikulum tidak terbatas pada seluruh mata pelajaran, namun meliputi segala sesuatu yang dapat memperoleh perkembangan siswa diantaranya yaitu pengembangan sikap, pengetahuan, dan keterampilan. Kurikulum yang digunakan dalam pendidikan saat ini yaitu kurikulum 2013, dalam kurikulum tersebut disusun untuk mewujudkan tujuan nasional dengan memperhatikan tahap perkembangan peserta didik dan kesesuaian dengan lingkungan, kebutuhan pembangunan nasional, pengembangan ilmu pengetahuan dan teknologi serta kesenian, sesuai dengan jenis dan jenjang masing-masing satuan pendidikan.

Pengembangan kurikulum perlu adanya dukungan dari masyarakat baik dalam pembiayaan maupun dalam memberikan umpan balik terhadap sistem pendidikan atau kurikulum yang sedang berjalan, selain itu dalam pengembangan kurikulum partisipasi guru sangat dibutuhkan untuk meningkatkan proses belajar mengajar. Partisipasi tersebut meliputi penetapan tujuan sekolah, penetapan program pendidikan atau kurikulum sekolah, dan penetapan strategi pelaksanaan. Kurikulum yang digunakan belum dilaksanakan secara maksimal, dari segi pemahaman guru ada yang harus ditingkatkan karena belum sesuai harapan. Sosialisasi yang minim juga dapat mengakibatkan tingkat pemahaman guru yang rendah terdahap kurtilas. Hotline Pendidikan Jawa Timur (Jatim) Surabaya melaksanakan survei yang dilaksanakan di bulan september hingga bulan oktober tahun 2013 dengan jumlah sasaran 240 guru SD dan SMP, berdasarkan hasil survei guru kurang dalam membuat perencanaan dan penetapan di sekolah, belum bisa sepenuhnya menjalankan sesuai pemerintah. (http://koran-sindo.com/node/342503).

Memahami kurikulum sama saja mengerti dengan proses pembelajaran yang digunakan, dalam kurikulum 2013 pembelajaran berlangsung berdasarkan tema, subtema dan beberapa mata pembelajaran. Pembelajaran IPS merupakan salah satu mata pelajaran yang termasuk ke dalam tema khususnya di sekolah dasar. Tujuan kurikulum IPS tahun 2004 yaitu mengkaji seperangkat fakta, peristiwa konsep, generalisasi yang berkaitan dengan perilaku manusia untuk membangun dirinya, masyarakatnya, bangsanya, dan lingkungannya berdasarkan pada pengalaman masa lalu yang dapat dimaknai untuk masa kini dan diantisipasi untuk masa yang akan datang.

Berdasarkan hasil wawancara yang dilakukan peneliti kepada wali kelas 4B yaitu Ibu Lia Mulyawati, S.Pd di SDN Panancangan 2 pada tanggal 08 November 2019, beliau mengatakan bahwa siswa merasa jenuh saat melaksanakan proses pembelajaran karena pembelajaran IPS yang monoton, selain itu siswa sulit menghafal dalam pembelajaran IPS. 
Oleh sebab itu agar pembelajaran IPS menyenangkan dan mudah untuk di hafal dibutuhkan media pembelajaran yang menarik.

Media pembelajaran sebagai alat bantu dibutuhkan oleh siswa karena dengan adanya media pembelajaran siswa lebih mudah untuk memahami materi yang diberikan. Menurut Sanaky dalam Nunuk dkk, (2018:4) media pembelajaran adalah sebuah alat yang berfungsi dan dapat digunakan untuk menyampaikan pesan pembelajaran. Memasuki era revolusi industri 4.0 guru dituntut untuk menguasai teknologi dan harus bisa menjelaskan bagaimana mengaplikasikannya. Teknologi memegang peranan penting dalam kehidupan budaya manusia.

Salah satu indikator kemajuan peradaban manusia dapat diukur dari kemajuan ilmu pengetahuan dan teknologi. Meskipun kini teknologi berkembang dan mudah untuk di akses namun peran guru tidak bisa tergantikan karena adanya teknologi. Guru harus mampu memanfaatkan teknologi sebagai media untuk menunjang proses pembelajaran.

Peneliti merumuskan masalah sebagai berikut. Bagaimana kelayakan media pembelajaran IPS berbasis video animasi pada tema indahnya keragaman di negeriku?, Bagaimana respon siswa terhadap media pembelajaran IPS berbasis video animasi pada tema indahnya keragaman di negeriku?. Adapun tujuan dari penelitian ini yaitu untuk mengetahui kelayakan media pembelajaran IPS berbasis video animasi pada tema indahnya keragaman di negeriku dan untuk mengetahui respon siswa terhadap media pembelajaran IPS berbasis video animasi pada tema indahnya keragaman di negeriku. Batasan-batasan masalah yang penulis teliti yaitu pada kelas IV SDN Panancangan 2 pada pelajaran tema 7 subtema 1 pada materi keragaman suku bangsa di indonesia dan media yang akan dibuat adalah video animasi. Adapun manfaat dari penelitian ini terbagi menjadi dua yaitu manfaat secara teoritis dan manfaat secara praktis.

\section{TINJAUAN TEORITIS}

Proses penyampaian ilmu pengetahuan dilakukan guru untuk mencapai tujuan pendidikan, tujuan tersebut dapat tercapai apabila siswa dapat memahami apa yang disampaikan oleh guru, untuk memudahkan guru dalam menyampaikan materi pembelajaran dibutuhkan media pembelajaran atau alat yang digunakan guru sehingga pembelajaran berlangsung secara efektif.

Menurut Suryani dan Agung dalam Nunuk dkk, (2018:4) media pembelajaran yaitu alat yang digunakan dalam pembelajaran, alat tersebut meliputi sarana yang membawa pesan 
sumber belajar untuk diberikan kepada siswa. Sejalan dengan pendapat Sanaky dalam Nunuk dkk, (2018:4) media pembelajaran adalah sebuah alat yang berfungsi dan dapat digunakan untuk menyampaikan pesan pembelajaran. Selain itu menurut Benni dalam Umar (2014:133) mendefinisikan media pembelajaran adalah sesuatu yang dapat membawa sumber berupa informasi yang diberikan oleh sumber kepada penerima informasi.

Video pembelajaran merupakan serangkaian gambar yang didalamnya terdapat isi berupa materi pembelajaran dan dapat menyampaikan pesan dari pengirim kepada penerima. Menurut Riyana dalam Wirasasmita dan Putra (2015:267) media video pembelajaran adalah media yang menyajikan audio dan visual yang berisi pesan-pesan pembelajaran baik yang berisi konsep, prinsip, prosedur, teori aplikasi pengetahuan untuk membantu pemahaman terhadap suatu materi pembelajaran, video dapat digunakan untuk menyampaikan pesan/materi pelajaran.

Sejalan dengan pendapat Rusman dalam Agustiningsih (2015:63) bahwa video pembelajaran merupakan bahan pembelajaran tampak dengar (audio visual) yang dapat digunakan untuk menyampaikan pesan-pesan/materi pelajaran. Selain itu menurut Muhibiddin Fadhli menurut Azhar Arsyad (2011:49) media video pembelajaran merupakan gambar-gambar dalam frame, dimana frame demi frame diproyeksikan melalui lensa proyektor secara mekanis sehingga pada layar terlihat gambar hidup.

IPS merupakan ilmu sosial yang didalamnya terdapat manusia dan masyarakat untuk menjalankan kegiatan-kegiatan sosial selain itu IPS dapat memecahkan masalah pribadi maupun sosial serta dapat mengambil keputusan untuk berpartisipasi dalam kegiatan masyarakat.

Menurut Yaba dalam Ujang Jamaludin dan Reza Rachmatullah (2018:1) menyatakan bahwa, IPS adalah ilmu sosial yang memiliki cabang dan ilmu lainnya lalu diolah berdasarkan prinsip dalam pendidikan dan tidak dijadikan program di sekolah. Sedangkan menurut Rudy Gunawan (2013:48) Ilmu sosial adalah ilmu yang mempunyai bahan kajian dalam penyederhanaan, seleksi, modifikasi, adaptasi dari keterampilan dan konsep sejarah, sosiologi, geografi, ekonomi, dan antropologi.

Selain itu menurut Nursid dalam Edy dan Mukminan (2017:3) IPS adalah penyederhanaan ilmu sosial, negara dan ilmu-ilmu lainnya yang terkait dengan masalah sosial yang disajikan untuk tujuan pendidikan pada tingkat sekolah dasar dan sekolah menengah. Sejalan dengan pendapat ahli sebelumnya menurut Sumaatja dalam Yulia (2016:6) IPS adalah ilmu yang dijadikan sebagai mata kuliah atau mata pelajaran yang didalamnya 
terdapat ilmu-ilmu sosial dan humaniora. Dalam arti bahwa kajian IPS sangat luas melalui pendekatan interdisipliner yang berkaitan dengan kehidupan sosial.

\section{METODE PENELITIAN}

Metode yang digunakan dalam penelitian ini adalah metode penelitian pengembangan (Reseach and Development) yaitu metode penelitian yang digunakan untuk menghasilkan produk tertentu untuk menguji keefektifan produk tersebut supaya dapat berfungsi di masyarakat luas Sugiyono (2014:407). Pada penelitian R\&D ini akan menghasilkan produk berupa video animasi pada tema 7 subtema 1 dalam materi keragaman suku bangsa di Indonesia. Cara menguji kelayakan dengan cara uji ahli dan uji terbatas.

\section{Desain Penelitian}

Desain penelitian yang diambil yaitu mengarah kepada desain pengembangan yang dilakukan oleh Sugiyoni yang dimodifikasi meliputi 6 langkah yaitu analisis masalah, pengumpulan data, desain produk, validasi desain, revisi desain, dan uji coba produk.

2. Teknik Pengumpulan Data

Teknik pengumpulan data dalam penelitian ini yaitu menggunakan wawancara, dokumentasi, angket penilaian uji kelayakan, dan angket respon siswa.

\section{Teknik Analisis Uji Instrumen}

Instrumen penelitian dan pengembangan ini menggunakan angket. Angket digunakan untuk subjek uji coba produk, yang bertujuan untuk mengetahui dan mengevaluasi sejauh mana kelayakan produk yang dihasilkan. Uji ahli meliputi ahli materi, ahli media, dan ahli pendidikan.

4. Teknik Analisis Data

Penelitian ini menggunakan analisis data deskriptif dengan menggunakan variabel pengembangan produk media pembelajaran serta variable kualitas media pembelajaran yang dihasilkan. Data yang diperoleh kemudian dikumpulkan dan dianalisis.

5. Indikator Keberhasilan

Indikator keberhasilan ini adalah produk yang dikembangkan berupa media pembelajaran berbasis video animasi pada materi keragaman suku bangsa di Indonesia dalam tema 7 sub tema 1 memenuhi kriteria keberhasilan. Adapun kriteria keberhasilannya yaitu: 1) penilaian validasi ahli materi, ahli media, dan ahli bahasa dengan minimal dapat dinyatakan dengan mendapatkan kategori cukup layak dengan 
kriteria kategori interpretasi $41-60 \%$; 2) respon siswa terhadap media video animasi minimal dinyatakan dengan mendapatkan kategori cukup dengan kriteria kategori interpretasi $41-60 \%$.

\section{HASIL PENELITIAN}

Penelitian ini dilaksanakan di SDN Panancangan 2 pada tanggal 08 November 2019 sampai tanggal 16 Maret 2020. Hasil penelitian pada pengembangan video ini mengacu kepada langkah-langkah yang telah dikembangkan oleh Sugiyono yaitu melakukan analisis masalah, pengumpulan data, desain produk, validasi produk, revisi produk, dan uji coba produk.

1. Analisis Masalah

Penelitian ini dilakukan dengan menganalisis masalah, pada tahap ini dilakukan analisis masalah diantaranya yaitu analisis kebutuhan, analisis kurikulum, dan analisis materi.

\section{Pengumpulan Data}

Adapun data dan informasi itu peneliti peroleh dari buku dan internet terkait dengan materi macam-macam suku bangsa di Indonesia, sehingga setelah semua data dan informasi ditentukan, peneliti melakukan penyesuaian materi untuk dijadikan video animasi.

3. Desain Produk

Desain yang dibuat oleh peneliti yaitu menggunakan animasi serta tulisan yang menarik sehingga membuat siswa tertarik untuk mengikuti pembelajaran. Font yang digunakan peneliti juga bervariasi serta warna tulisan yang digunakan.

4. Validasi Desain

Validasi ini bertujuan untuk mengetahui media pembelajaran yang telah dikembangkan berupa video animasi telah memenuhi kriteria kelayakan atau belum. Media pembelajaran berupa video animasi akan dilakukan uji validasi oleh ahli materi, ahli media, dan ahli bahasa.

\section{a. Uji Ahli Materi}

Berikut ini adalah analisis data penilaian validasi ahli materi yang disajikan dalam tabel berikut:

Tabel Penilaian Uji Ahli Materi 


\begin{tabular}{|c|c|c|}
\hline No & Aspek yang dinilai & Skor Penilaian Ahli Materi \\
\hline 1 & Penilaian isi & 40 \\
\hline 2 & Kelayakan penyajian & 25 \\
\hline \multicolumn{2}{|c|}{ Jumlah skor mentah } & 65 \\
\hline \multicolumn{2}{|c|}{ Jumlah skor ideal } & 75 \\
\hline \multirow{2}{*}{ NP (\%) } & $\frac{65}{75} \times 100 \%=86,7 \%$ \\
\hline
\end{tabular}

Berdasarkan tabel data penilian uji ahli materi diperoleh skor aspek penilaian isi sebesar 40 dari 9 penyataan dan aspek kelayakan penyajian sebesar 25 dari 6 pernyataan, sehingga jumlah skor mentah sebesar 65 dan skor ideal 75. Berdasarkan hasil validasi ahli materi media pembelajaran IPS berbasis video animasi mendapat nilai presentase sebesar $86,7 \%$ masuk pada ketegori "sangat layak".

b. Uji Ahli Media

Berikut ini adalah analisis data penilaian validasi ahli media yang disajikan dalam tabel berikut:

Tabel Penilaian Uji Ahli Media

\begin{tabular}{|c|l|c|}
\hline No & Aspek yang dinilai & Skor Penilaian Ahli Media \\
\hline 1 & Tampilan & 47 \\
\hline 2 & Pemanfaatan & 15 \\
\hline 3 & Penggunaan & 7 \\
\hline \multicolumn{2}{c}{ Jumlah skor mentah } & 69 \\
\hline & Jumlah skor ideal & 100 \\
\hline & NP (\%) & $\frac{69}{100} \times 100 \%=69 \%$ \\
\hline & Kriteria kategori interpretasi & Layak \\
\hline
\end{tabular}

Berdasarkan tabel data penilian uji ahli media diperoleh skor aspek tampilan sebesar 47 dari 13 penyataan, aspek pemanfaatan sebesar 15 dari 4 pernyataan, dan aspek penggunaan sebesar 7 dari 3 penyataan, sehingga jumlah skor mentah sebesar 69 dan skor ideal 100. Berdasarkan hasil validasi ahli media terhadap media pembelajaran berbasis video animasi mendapat nilai presentase sebesar 69\% masuk pada ketegori "layak".

c. Uji Ahli Bahasa

Berikut ini adalah analisis data penilaian validasi ahli media yang disajikan dalam tabel berikut: 
Tabel Penilaian Uji Ahli Bahasa

\begin{tabular}{|c|c|c|}
\hline No & Aspek yang dinilai & Skor Penilaian Ahli Bahasa \\
\hline 1 & Kebahasaan & 42 \\
\hline Jumlah skor mentah & 42 \\
\hline Jumlah skor ideal & 50 \\
\hline NP $(\%)$ & $\frac{42}{50} \times 100 \%=84 \%$ \\
\hline \multicolumn{2}{|c|}{ Kriteria kategori interpretasi } & Sangat Layak \\
\hline
\end{tabular}

Berdasarkan tabel data penilian uji ahli bahasa diperoleh skor aspek kebahasaan sebesar 42 dari 10 penyataan, sehingga jumlah skor mentah sebesar 42 dan skor ideal 50. Berdasarkan hasil validasi ahli bahasa terhadap media pembelajaran berbasis video animasi mendapat nilai presentase sebesar 84\% masuk pada ketegori "Sangat Layak".

\section{Revisi Produk}

Revisi produk media pembelajaran yang sudah divalidasi oleh ahli materi, ahli media, dan ahli bahasa selanjutnya direvisi dengan komentar dan saran pada saat melakukan validasi.

6. Uji Coba Produk

Uji coba dilakukan di SDN Panancangan 2 pada 20 orang siswa kelas IV, uji coba terbatas ini untuk mengetahui respon siswa terhadap media pembelajaran video animasi. Adapun data hasil penilaian respon siswa terhadap media pembelajaran IPS berbasis video animasi disajikan dalam tabel berikut.

Tabel Hasil Respon Siswa

\begin{tabular}{|c|l|c|c|}
\hline No & \multicolumn{1}{|c|}{ Aspek } & Skor & Nilai Akhir (\%) \\
\hline 1 & Tampilan & 517 & $86,2 \%$ \\
\hline 2 & Penyajian Materi & 181 & $90,5 \%$ \\
\hline 3 & Ketertarikan & 180 & $90 \%$ \\
\hline \multicolumn{2}{|c|}{ Skor Total } & $\mathbf{8 7 8}$ & $\mathbf{8 8 , 9 \%}$ \\
\hline
\end{tabular}

Berdasarkan tabel diatas, hasil respon siswa terhadap video animasi diperoleh persentase nilai akhir sebesar $88,9 \%$ masuk dalam kategori "sangat baik".

7. Indikator keberhasilan

Setelah melakukan beberapa tahap diantaranya yaitu potensi dan masalah, pengumpulan data, desain produk, uji validasi, revisi produk, uji coba produk maka akan menghasilkan produk berupa media pembelajaran IPS berbasis video animasi 
pada materi macam-macam suku bangsa di Indonesia. Produk ini dimasukkan ke dalam CD/DVD dan dalam bentuk softcopy.

\section{PEMBAHASAN}

Langkah pertama dalam penelitian ini peneliti melakukan analisis masalah, diantaranya yaitu analisis kebutuhan, analisis kurikulum, dan analisis materi. Pada analisis kebutuhan peneliti melakukan wawancara tidak struktur kepada Ibu Lia Mulyawati, S.Pd pada tanggal 8 November 2019, selanjutnya setelah melakukan analisis kebutuhan peneliti melakukan analisis kurikulum yang mengacu pada KI dan KD dalam kurikulum 2013, setelah melakukan analisis kurikulum peneliti melakukan analisis materi tentang macam-macam suku bangsa di Indonesia yang terdapat dalam tema 7 yaitu indahnya keragaman di Negeriku.

Selanjutnya dilakukan tahap pengumpulan data, peneliti melakukan pengumpulan data berupa gambar, materi, tulisan, dan musik dalam video animasi. Setelah dikumpulkan data tersebut, lalu peneliti menggabungkan data dan menyesuaikan dengan materi yang akan dijadikan video animasi.

Tahap selanjutnya yaitu desain produk, pada tahap ini peneliti membuat story board terlebih dahulu yang bertujuan untuk memudahkan peneliti dalam membuat video animasi. Selanjutnya dilakukan tahap pembuatan desain produk meliputi pembukaan, isi atau materi, dan penutup dalam video animasi. Desain yang dibuat oleh peneliti dalam pembukaan terdapat judul, gambar animasi, serta background yang disesuaikan dengan tema. Selanjutnya bagian isi atau materi peneliti membuat desain dengan tulisan berupa pertanyaan untuk menggali pengetahuan siswa tentang keragaman, lalu pada slide berikutnya peneliti menjelaskan keragaman dan macam-macam suku bangsa di Indonesia. Selanjutnya bagian penutup peneliti membuat pertanyaan serta memberikan semangat kepada siswa.

Tahap selanjutnya yaitu validasi desain, dalam tahap ini validasi desain bertujuan untuk mengetahui kelayakan media pembelajaran IPS berbasis video animasi. Pada tahap ini dilakukan oleh 3 ahli yaitu ahli materi, ahli media, dan ahli bahasa. Setelah melakukan validasi desain peneliti mendapatkan perolehan skor dari setiap masing-masing validator sebagai berikut.

Tabel Rata-rata Skor Validasi Ahli

\begin{tabular}{|c|c|c|}
\hline Hasil Validasi & Presentase (\%) & Kategori \\
\hline Ahli Materi & $86,7 \%$ & Sangat Layak \\
\hline Ahli Media & $69 \%$ & Layak \\
\hline Ahli Bahasa & $84 \%$ & Sangat Layak \\
\hline
\end{tabular}




\begin{tabular}{|c|c|c|}
\hline Rata-rata & $\mathbf{7 9 , 9 \%}$ & Layak \\
\hline
\end{tabular}

Berdasarkan tabel diatas menunjukan skor tertinggi didapatkan dari hasil validasi ahli materi sebesar $86,7 \%$ dengan kategori sangat layak. Hal tersebut menunjukan bahwa pengembangan media pembelajaran IPS berbasis video animasi telah memenuhi salah satu kriteria indikator keberhasilan. Selanjutnya dari hasil validasi ahli media sebesar $69 \%$ dengan kategori sangat layak, hal tersebut menunjukan bahwa pengembangan media pembelajaran IPS berbasis video animasi telah memenuhi salah satu kriteria indikator keberhasilan.

Selanjutnya hasil ahli bahasa sebesar $84 \%$ dengan kategori sangat layak, hal tesebut menunjukan bahwa pengembangan media pembelajaran IPS berbasis video animasi telah memenuhi salah satu kriteria indikator keberhasilan. Dari hasil penelitian validasi ahli media pembelajaran IPS berbasis video animasi memperoleh presentase sebesar 79,9\% dan termasuk dalam kategori layak.

Tahap selanjutnya yaitu melakukan uji coba produk, pada tahap ini peneliti melakukan uji coba terbatas kepada 20 orang siswa kelas IV di SDN Panancangan 2. Pada tahap ini terdapat 3 aspek pada angket respon siswa terhadap media pembelajaran IPS berbasis video animasi yaitu aspek tampilan, aspek penyajian materi, dan aspek ketertarikan. Pada aspek tampilan memperoleh skor sebesar 517 dengan nilai akhir 86,2\% masuk dalam kategori "sangat baik", hal ini menunjukan bahwa aspek tampilan seperti gambar, tulisan, warna, dan musik mempunyai respon yang sangat baik.

Selanjutnya hasil respon siswa dalam aspek penyajian materi memperoleh skor sebesar 181 dengan nilai akhir 90,5\% masuk dalam kategori "sangat baik", hal ini menunjukan bahwa aspek materi yang disajikan oleh peneliti sangat baik sehingga mudah dipahami oleh siswa. Selanjutnya hasil respon siswa pada aspek ketertarikan dengan skor sebesar 180 dengan nilai akhir 90\% masuk dalam kategori "sangat baik" hal ini menunjukan bahwa siswa senang dan bersemangat saat menonton video animasi.

Hasil uji terbatas pada media pembelajaran IPS berbasis video animasi mendapatkan skor total sebesar 878 dengan nilai akhir $88,9 \%$ masuk dalam kategori "sangat baik", hal ini menunjukan respon siswa yang sangat baik dalam melakukan proses pembelajaran menggunakan video animasi.

Berdasarkan pembahasan tersebut menunjukan bahwa media pembelajaran IPS berbasis video animasi termasuk dalam kategori layak dan memperoleh kategori sangat baik dalam respon yang diberikan siswa. Diharapkan media pembelajaran IPS berbasis video 
animasi ini dapat membantu guru dalam menjelaskan materi IPS terutama dalam materi macam-macam suku bangsa di Indonesia dan dapat memudahkan siswa dalam memahami materi tersebut. Selain itu juga diharapkan media ini dapat meningkatkan mutu pendidikan disekolah dan dapat menambah referensi media pembelajaran.

\section{KESIMPULAN}

Berdasarkan hasil penelitian dan pembahasan pada pengembangan media pembelajaran IPS berbasis video animasi pada tema indahnya keragaman di Negeriku pada kelas IV di SDN Panancangan 2 maka peneliti dapat mengambil simpulan bahwa penelitian yang dilakukan menggunakan metode penelitian R\&D dengan menggunakan desain penelitian yang dikembangkan oleh Sugiyono diantaranya yaitu analisis masalah, pengumpulan data, desain produk, validasi desain produk, revisi produk, dan uji coba terbatas.

Hasil penelitian menunjukan bahwa validasi oleh ahli materi termasuk kedalam kategori "sangat layak" dengan nilai rata-rata yang diperoleh sebesar 86,7\%. Selain itu hasil validasi oleh ahli media termasuk kedalam kategori "layak" dengan nilai rata-rata yang diperoleh sebesar 69\%. Selanjutnya hasil validasi oleh ahli bahasa termasuk kedalam kategori "sangat layak" dengan nilai rata-rata yang diperoleh sebesar 84\%. Adapun hasil dari angket respon siswa pada uji coba terbatas termasuk dalam kategori "sangat baik" dengan presentasi sebesar $88,9 \%$. Berdasarkan hasil tersebut, produk akhir berupa media pembelajaran IPS berbasis video animasi yang dihasilkan layak digunakan dalam proses pembelajaran IPS siswa kelas IV.

\section{SARAN}

Penulis memberikan saran berdasarkan hasil penelitian media pembelajaran IPS berbasis video animasi diantaranya yaitu:

1. Bagi peneliti yang ini mengembangkan media pembelajaran IPS berbasis video animasi khususnya dalam materi macam-macam suku bangsa di Indonesia bisa menambahkan materi tentang adat istiadat suku bangsa di Indonesia agar video animasi tersebut lebih luas dalam segi materi pembelajaran.

2. Hal-hal yang perlu diperhatikan dalam video animasi ini yaitu musik yang menyenangkan, ukuran tulisan, gambar yang jelas, kualitas suara, dan warna yang digunakan harus kontras 
dengan background, sehingga dapat menghasilkan video animasi yang lebih menarik dan lebih layak untuk digunakan dalam proses pembelajaran siswa.

3. Produk pengembangan media pembelajaran IPS berbasis video animasi ini dapat digunakan sebagai alternatif pilihan yang dapat dipergunakan pada tema indahnya keragaman di negeriku, khususnya pada materi macam-macam suku bangsa di indonesia pada kelas IV semester 2 untuk memudahkan guru dalam menyampaikan materi dan memudahkan siswa dalam memahami materi pelajaran.

\section{DAFTAR PUSTAKA}

Agustiningsih. "Video" Sebagai Alternatif Media Pembelajaran dalam Rangka Mendukung Keberhasilan Penerapan Kurikulum 2013 di Sekolah Dasar. Vol.4 No.1 Hal.63.

Arsyad, Azhar. 2011. Media Pembelajaran. Jakarta: PT. Raja Grafindo Persada.

Gunawan, Rudy. 2013. Pendidikan IPS Filosofi, Konsep, dan Aplikasi. Bandung: Alfabeta.

Hidayatullah, Priyanto, M. Amarullah Akbar \& Zaky Rahim. 2011. Animasi Pendidikan Menggunakan Flash. Bandung : Informatika Bandung.

Jamaludin, Ujang dan Rachmatullah, Reza. 2018. Pembelajaran Pendidikan IPS Teori Konsep dan Aplikasi Bagi Guru dan Mahasiswa. Bekasi: CV Nurani.

Siska, Yulia. 2016. Konsep Dasar IPS. Yogyakarta: Garudhawaca.

Sugiyono. 2014. Metode Penelitian Pendidikan Pendekatan Kuantitatif, Kualitatif, dan R\&D. Bandung: Alfabeta.

Surahman, Edy dan Mukminan. 2017. Peran Guru IPS Sebagai Pendidik dan Pengajar dalam Meningkatkan Sikap Sosial dan Tanggung Jawab Sosial Siswa SMP. Jurnal Pendidikan IPS. Vol.4. No.01. Hal.03.

Suryani, Nunuk, dkk. 2018. Media Pembelajaran Inovatif. Bandung: PT Remaja Rosdakarya.

Umar. 2014. Media Pendidikan: Peran dan Fungsinya dalam Pembelajaran. Jurnal Tarbawiyah. Vol.11 No.1. Hal.138-139.

Wirasasmita, Rasyid Hardi dan Putra, Yupi Kuspandi. 2015. Pengembangan Media Pembelajaran Video Tutorial Interaktif Menggunakan Aplikasi Camtasia Studio dan Macromedia Flash. Jurnal Educatio Vol. 10 No.2. Hal 262-279. 